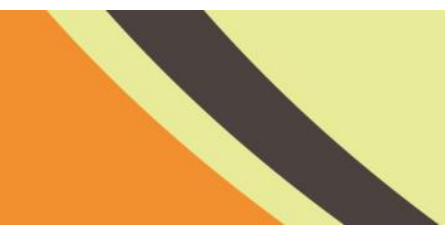

\title{
Assistance and Training of Compost Products from Organic Waste at SMA Negeri I Tanjung Raja, Ogan Ilir, South Sumatra
}

\author{
ES Yusmartini ${ }^{1}$, Mardwita Mardwital, and Aseptianova ${ }^{2 .}$ \\ ${ }^{1}$ Chemical Engineering Department, Faculty of Engineering, Universitas Muhammadiyah Palembang. Indonesia \\ ${ }^{2}$ Faculty of Teacher Training and Education, Biology Education Study Program, Universitas Muhammdiyah Palembang. Indonesia \\ Corresponding author: eka.yusmartini@gmail.com
}

\section{ARTICLE INFO}

Article History:

Received: 15 September 21

Final Revision: 10 November 21

Accepted: 12 November 21

Online Publication: 20 November 21

\section{KEYWORDS}

organic waste, fermentation, compost, community service

\section{CORRESPONDING AUTHOR}

*E-mail: eka.yusmartini@gmail.com

\section{A B S T T R A C T}

\begin{abstract}
The waste problem is never solved. The increase in the amount of waste every day is following the rate of population growth and activities carried out by the community. Tanjung Raja is the oldest district in Ogan Ilir Regency, South Sumatra, Indonesia. One of the educational facilities in Tanjung Raja is SMA Negeri (state-owned Senior High School) No. I Tanjung Raja. Related to school environmental problems, especially to reduce the waste that will be brought to the Landfill, SMA Negeri I Tanjung Raja has not done waste sorting. During this time the garbage collected in the place that has been provided according to its designation will be thrown into the Temporary Landfill. Based on the results of observations and interviews with partners, the PKM community services activities that will be carried out are processing waste generated from school activities. The activity will be done by sorting the resulting waste, then continued by making compost from the leaves produced in school and also other organic waste into compost. PKM community service activities have produced compost products from organic materials. Partners have come up with solutions to address the waste generated from daily activities and fallen leaves. The compost produced is economically valuable. This activity can overcome the problem of waste in schools and is also useful in preserving the school environment.
\end{abstract}

\section{INTRODUCTION}

Waste management according to Government Regulation of the Republic of Indonesia No. 81 of 2012 [1] on Household Waste Management and similar Waste requires that waste before being taken to landfills must be reduced or attempted to reduce the amount of waste from the source of waste before finally being taken to a landfill. Household waste is the waste that comes from commercial areas, industrial areas, special areas, social facilities, public facilities, and / other facilities.

Tanjung Raja is the oldest district in Ogan Ilir Regency, South Sumatra, Indonesia. The majority of Tanjung Raja district residents work as farmers, and a small percentage as civil servants. The inhabitants of this region are tribal Pegagan, Kayuagung, and Java. The colloquis used are Indonesian, Palembang, Bahasa Pegagan and Kayuagung. One of the educational facilities in Tanjung Raja is SMA Negeri (Stateowned Senior High School) I Tanjung Raja. The location of the school is located on Jalan Merdeka Number 57 Tanjung Raja. The current number of students is 750 , consisting of 222 men and 528 women. While the teaching staff numbered 41 people, with educational qualifications S1 (Undergraduate degree) as many as 36 people and S2 (Master degree) as many as 5 people.

Related to school environmental problems, especially to reduce the waste that will be brought to the Landfill, SMA (Stateowned Senior High School) Negeri I Tanjung Raja has not done waste sorting. During this time the waste collected in the place that has been provided according to its designation will be disposed of to the Temporary Landfill, which is located next to the partner. The temporary dump is located in Tanjung Raja Market. The daily waste that goes into the Landfill in Ogan Ilir is 40-100 tons per day [2]. The type of garbage that is taken to the Temporary Landfill and finally to the Landfill is dominated by organic waste. Pollution that occurs will have an impact on the surrounding environment, where pollution to air pollution caused by odors, and also to the soil, can come from the buildup of organic waste [3]. 
Janitors collect garbage, both from fallen leaves in the schoolyard, garbage from the school cafeteria, garbage student activities, garbage from administrative activities, and others, only carried out by an officer. Every day the collected garbage is taken to the Tanjung Raja Market Temporary Dump. The provision of waste collection facilities becomes useless because in the end the garbage is put together again thrown into the Landfill (Figure 1).
Leaf waste that is widely found in partners is the dominant waste from the waste generated every day. Mitra once tried to collect the leaves along with other waste produced in school but caused a new problem, namely the accumulation of garbage into increasingly high mountains of garbage, so that this activity is no longer carried out.
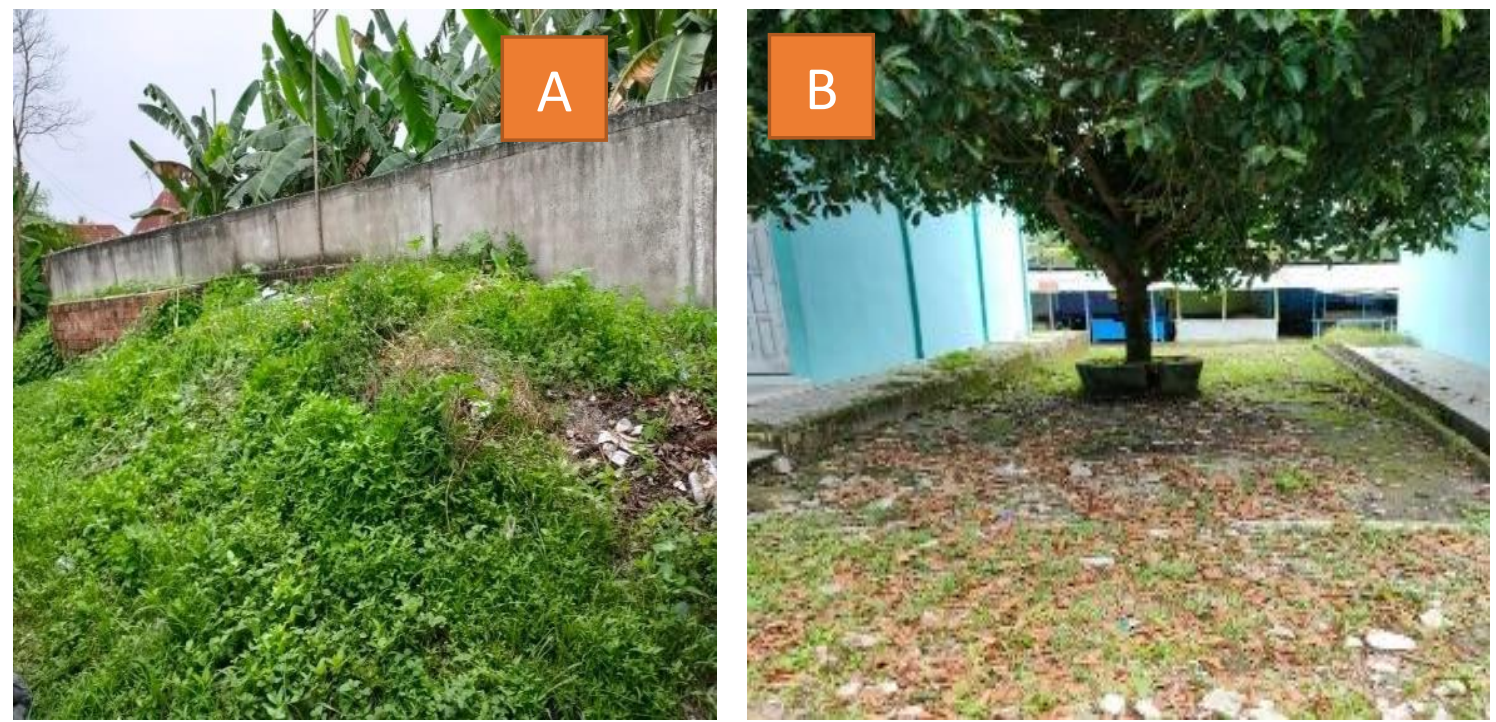

Fig. 1. The location of the pile of garbage (A) and one of the sources of waste generation (B).

Organic waste and organic waste caused by school activities are immediately disposed of without any separation between organic and inorganic waste. Organic waste according to Ref. [4], is a type of garbage that is mostly composed of organic compounds in the form of plant, animal, or animal waste. This waste is easily decomposed by microorganisms. The usefulness of leaf litter is very high [5]. It is also stated by Ref. [6], which states that waste from vegetables including leaves is very good if processed into organic compost.

Based on the results of observations and interviews with partners, related to the above, the PKM community service activities that will be carried out are processing waste generated from school activities. The activity will be done by sorting the resulting waste, then continued by making compost from the leaves produced in school and also other organic waste into compost.

\section{MATERIALS AND METHODS}

The implementation method in this PKM is divided into three stages, namely the planning or pre-implementation stage, the implementation stage, and the evaluation stage.

The planning stage is done by conducting an interview, to find out the problems that exist in the partner. and the solutions that can be offered to overcome the problem. Identification of problems and solutions that can be offered is done by digging up information in partners. Extracting information is done using communication tools such as telephone interviews, and messaging applications. In addition, the interview is also conducted directly to the partner to find out the conditions on the ground.
The implementation stage is carried out by socialization, mentoring, and training of partners. Socialization is done directly, while still using health protocols following covid-19 standards. At this stage, there is also a selection of places to carry out activities agreed between the PKM Community Service Team and partners. Activities include the provision of necessary facilities and infrastructure. Furthermore, the assistance and training of microbial manufacturing and its use for fermentation at the time of composting.

Evaluation of the success of community partnership program activities is carried out using google form before the activity is carried out and after the activity is carried out, by providing some questions related to the activities carried out. The benchmark of this evaluation is the partner's understanding of composting and manufacturing training.

\section{RESULT AND DISCUSSION}

\subsection{Planning Stage}

Based on the results of interviews and direct review of the location, it was obtained that the priority problem in partners is how to manage waste, especially leaves that are produced from many tree trees in the school environment and also the emergence of organic waste from daily activities. Especially for organic waste, the school has also not done the sorting of organic and organic waste. All are immediately thrown into the existing polling station in the market whose position is adjacent to the partner.

This PKM community service activity was carried out at Sma Negeri I Tanjung Raja located in Ogan Ilir, South Sumatra. The solutions offered based on existing problems are: 
1. Doing socialization and mentoring about waste management in schools

2. Provision of facilities and infrastructure for the creation of compost activities made from organic waste resulting from activities in partners

3. Assisting and training in making microbes that will be used in the fermentation process of composting.

4. Composting and manufacturing training uses solid bacteria.

The activities are carried out offline using the covid-19 health protocol. The school is also already taking place face-to-face, only on Saturdays. Teachers and students who participate in this activity are representatives of teachers and students in school. The selection of teachers and representative students is selected based on the field of the teacher concerned and the student based on the school's extracurricular activities related to environmental issues.

\subsection{Implementation Stage}

The implementation of the service is carried out following the agreement with partners in overcoming existing problems. The first stage is the socialization of teachers and students in school. Teachers and students have involved as many as 31 teachers and 25 students. Material is delivered in the form of presentations and discussions. The role of teachers and students in participating in these activities is very good. Students who are representatives follow the activities with great enthusiasm. In socialization is given an understanding of the need to manage and separate between organic waste and organic waste. Socialization also provides one solution to manage waste and is useful and worth selling is to make compost. This activity also introduced how to make eco enzymes to reduce the incidence of waste thrown into the environment. The focus of activities is still done by making compost from organic waste in the partner environment, especially the leaves in the school location (Figure 2).
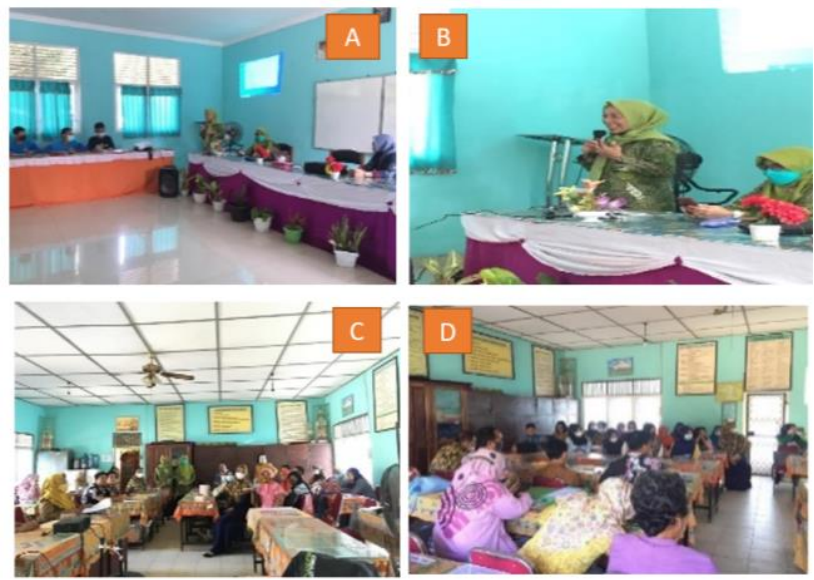

Fig. 2. Socialization program to the students (A, B), Socialization program to the teachers $(\mathrm{C}, \mathrm{D})$.

The next stage determines the location where composting activities are made from leaf waste in school. After the determination of the location is agreed upon by the partner, then the creation of the necessary facilities and infrastructure is carried out. This is done because there has been no previous effort made by partners to process organic waste into compost. Development preparation for compost processing, carried out by the PKM team while still coordinating with partners.

https:// doi.org/10.29165/ajarcde.v5i3.79
The building will be used as a center for organic waste processing activities into compost, measuring $3 \times 3$, partially walled, and using trellises and trellis doors. Equipment prepared in the form of a chopping engine, with a capacity specification of $50 \mathrm{~kg}$ /hour, gasoline motor drive, and $1 \mathrm{HP}$ power (Figure 3). The use of a chopping machine will make the garbage becomes the same size and small. Small materials will be faster the composting process because the wider the material touched by bacteria [4].

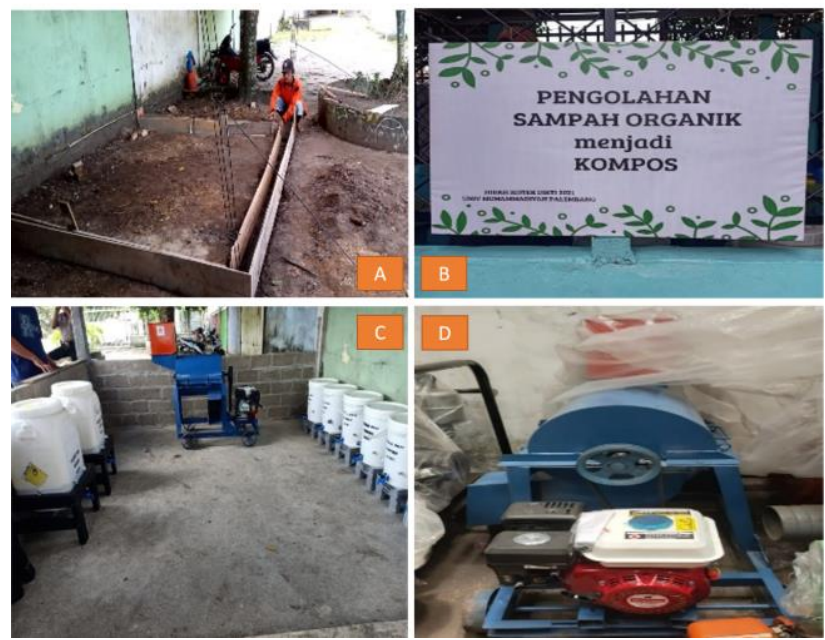

Fig.3. Building preparation (A). The building has been ready (B), chopping machine (C) and composter and chopping machine (D)

Compost is prepared using anaerobic system, and prepared as many as 9 composters. This is done deliberately so that if you want to move it will be easier. Compost is also equipped with a filtered stand to put solid material that will be fermented into compost and there is also a faucet prepared under the filter (Figure 4). This allows the flow of leachate to separate from the solid material and form it into a liquid fertilizer [7]. This is in line with what is conveyed by Ref. [8,9], that leachate from the composting of organic waste can be processed into liquid fertilizer because leachate contains nutrients, organic matter that is high enough that can increase the activity of microorganisms in degrading organic waste. Other equipment prepared is shovels, hoes, lorries, and syings.
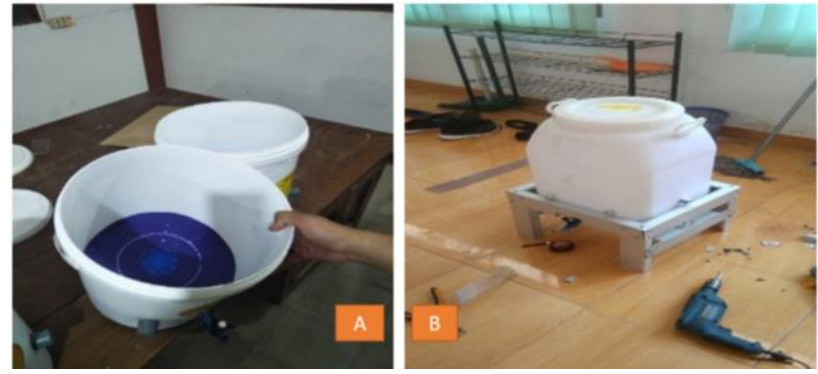

Fig, 4. Filter in composter (A) and composter (B)

The excitement of training and mentoring the manufacture of microbes that will be used in fermentation is given to 25 students and 10 companion teachers. Companion teachers are related to the activities of students who take environmental issue materials as extracurricular activities. The assistance of making microbes that will be used is done before composting. The manufacture of 
microbes uses materials in the form of rice bran that is filtered first until it is very smooth in shape. The ingredients are then added with rice flour, Yakult, and molasses. The three ingredients are stirred, mixed well then added molasses. The mixture is then placed in a tightly sealed, airtight container for 7 days for the fermentation process (Fig. 5).

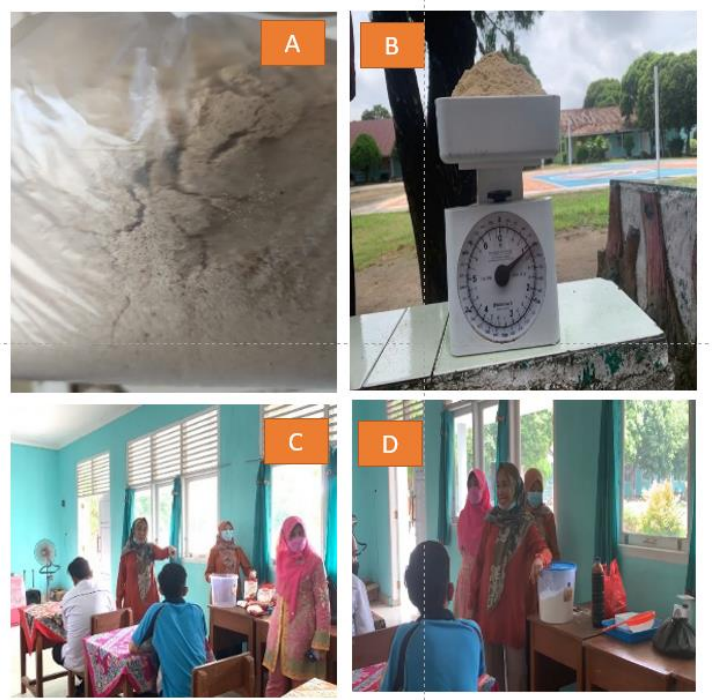

Fig.5. rice bran (A), sifted rice bran (B), making the solid bacteria $(\mathrm{C}$ dan $\mathrm{D})$.

Composting and manufacturing training is carried out after all preparations have been completed. Shiva is very enthusiastic about training in composting. Training begins by dissolving fermented solid bacteria with water and adding more molasses. Then organic material in the form of leaves collected from the schoolyard and other organic materials was chopped using a chopping engine, so it has the same size and smaller than the original material. The microbial solution that has been prepared was given to chopped materials (Figure 6). Once well-stirred then stored into the compost that has been prepared, fermented for 14 days aerobically. After 14 days the resulting compost is then resyringed, resulting in a more attractive product, and the resulting compost color is close to the black color of the soil. The resulting compost is then packaged in packaging with a logo that has been prepared.

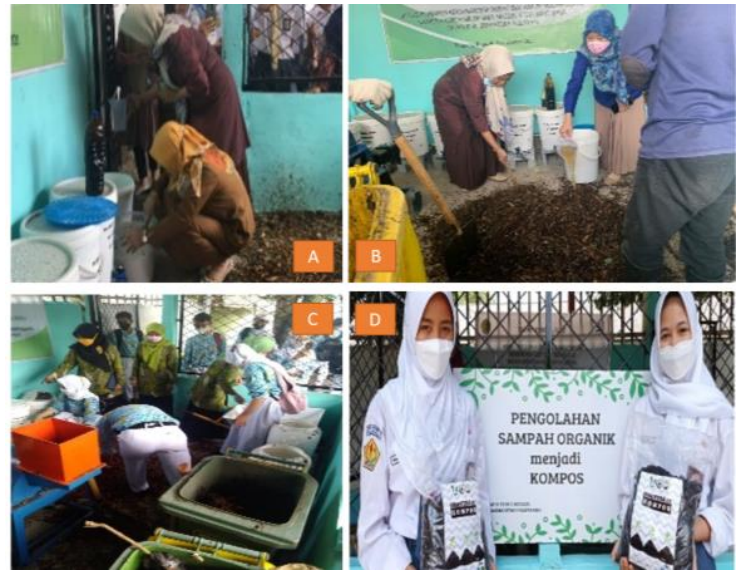

Fig.6. making solution (A). mixing organic matter and microbes (B), composting into the composter (C) dan compost products (D)

\subsection{Evaluation}

Evaluation results based on benchmarks of partner understanding of composting and composting training conducted before and after training are shown in Figure 9. Based on this, it saw a significant increase. The level of understanding of students before this activity was $35.56 \%$, after the implementation of assistance and waste processing management training, the student's understanding level increased to $91.11 \%$. Waste management by making compost products, making waste economically valuable (Figure 7).

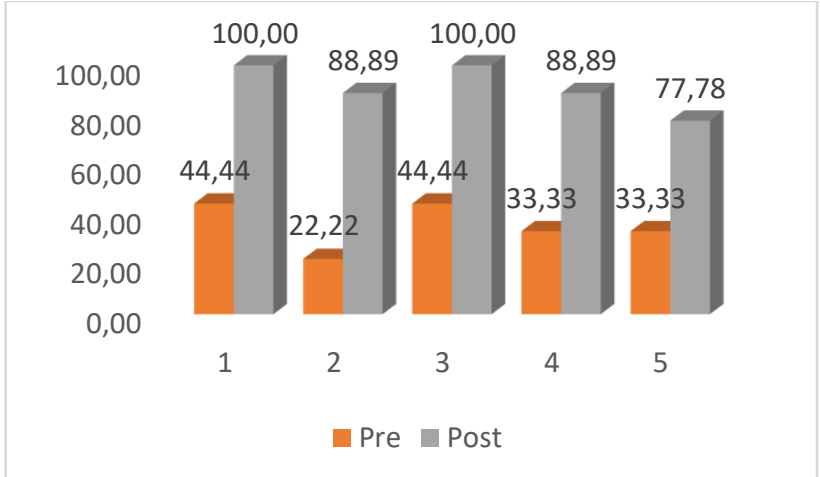

Fig. 7. The result of the evaluation of understanding before and before mentoring

So based on the results of the evaluation it can be said that the success of the program will have an impact on the continuity of the program that has been carried out. The role of a very supportive partner and also a solid PKM Team makes the success of this program can be carried out.

\section{CONCLUSION}

PKM devotional activities carried out have produced compost products from organic materials. Partners have come up with solutions to address the waste generated from daily activities and fallen leaves. The compost produced is economically valuable. This activity can overcome the problem of waste in schools and is also useful in preserving the school environment. This compost production activity is expected to continue to be continuously implemented, so it will be one of the sources of partner income. In addition, this activity can be used as additional material in the school curriculum, related to student extracurricular activities. Students involved in this activity have environmental extracurricular activities, so that compost production can continue to be sustainable.

\section{ACKNOWLEDGMENT}

The author thanked the 'Directorate of Research and Community Service Deputy for Research Development and Ministry, Ministry of Research and Technology / National Research and Innovation Agency' who has financed the Implementation of Community Service Program under Contract Number: 1174 /SP2H/PPM/DRPM/2021, dated April 19, 2021. The author also thanked the Principal and Staff and Teachers of teachers and students at State High School I Tanjung Raja Ogan Ilir as PKM partners. 


\section{REFERENCE}

[1] Peraturan Pemerintah Republik Indonesia Nomor 81 Tentang Pengelolaan Sampah Rumah Tangga dan Sampah Sejenis Sampah Rumah Tangga.

[2] https://palembang.tribunnews.com/2013/18/100-tonsampah-per-hari

[3] E.S.Yusmartini, D. Setiabudidaya, Ridwan, Marsi and Faizal, " Characteristic of Leachate at Sukawinatan Landfill, Palembang, Indonesia," in Journal of Physics: Conference Series 423(423)012048, IOP Publishing.

[4] T.Nur, A.R.Noor, M.Elma,"Pembuatan Pupuk Organik Cair Dari Sampah Organik Rumah Tangga Dengan Penambahan Bioaktivator EM4, "Jurnal Konversi vol.5 no.2, pp.5-12, Oktober 2016.

[5] E.Setyaningsih, D.S.Astuti, R. Astuti, "Kompos Daun Solusi Kreatif Pengendali Limbah,"Jurnal Bioeksperimen,vol.3 no.2, pp 45-51, September 2017.
[6] Sulistyorini dan Lilis, "Pengelolaan Sampah Dengan Menjadikannya Kompos,” Jurnal Kesehatan Lingkungan vol 2, no.1, pp 77-84, 2005.

[7] Hadisuwito, Sukamto, Membuat Pupuk Kompos Cair. Cetakan Ketiga, Agromedia Pustaka, Jakarta, 2007

[8] D. Yomi, A. Ichsan, "Studi Optimasi Kematangan Kompos dari Sampah Organik dengan Penambahan Bioaktivator Limbah Rumen dan Air Leachate", Seminar Nasional Sains \& Teknologi Lingkungan, Padang 19 Oktober 2007

[9] E.S.Yusmartini, Mardwita, I.N.Fahmi, : "Sosialisasi Pengolahan Leachate Menjadi Pupuk Cair Di TPS-3R Kelurahan Talang Kelapa KecamatanAlang-Alang Lebar Palembang Sumatera Selatan”, Jurnal Widya Laksana vol. 10 no. 1 , pp.33-37, 2021. 